\title{
Body weight and growth rate of South African Angora goat kids under different pre- and post-weaning management systems
}

\author{
M.A. Snyman ${ }^{\#}$ \\ Grootfontein Agricultural Development Institute, Private Bag X529, Middelburg (EC) 5900, South Africa
}

\begin{abstract}
The data used for this study were collected on 16644 kids born between 2000 and 2004 in 12 different Angora goat studs representing different management systems. Body weight and growth rate of kids from birth to 16 months of age, as well the 18- and 21-month body weights and first kidding performance of ewe kids were evaluated. Variable growth rates were recorded among kids in the different studs, which can be ascribed largely to different environments and supplementary feeding practices. The pre-weaning growth performance of both ram and ewe kids was satisfactory. However, the same did not apply for post-weaning growth rates. In those flocks where kids did not receive any supplementary feeding after weaning, their body weights remained virtually constant from weaning up to eight months of age. This phenomenon where especially ewe kids did not grow well after weaning, needs to be investigated further, since it influences the reproductive ability of young ewes directly. This was evident from the poor reproductive performance of young ewes in some of the studs. On the other hand, the effect of different pre-weaning treatments did not seem to be carried over to body weight and reproductive performance at first kidding age.
\end{abstract}

Keywords: Angora goats, growth rate, reproduction

\#E-mail: grethasn@nda.agric.za

\section{Introduction}

Pre- and post-weaning growth rate in Angora goats are more related to survival rate of kids and to young goats reaching an acceptable weight at mating age than to the marketing of meat. It is generally accepted that the lower limit of body weight at which young Angora ewes can be expected to conceive successfully, is $25 \mathrm{~kg}$ (Van der Westhuizen et al., 2004). The relatively poor growth rate of Angora kids (Yalcin, 1982; Nicoll, 1985; Nicoll et al., 1989; Gifford et al., 1991) compared to other small-stock breeds is well known. Many young ewes do not reach the target weight at 18 months of age when they are mated for the first time. Furthermore, data on early growth rates in South African Angora goats are lacking in the literature, with only recorded body weights at twotooth age are available (Snyman \& Olivier, 1996; Snyman \& Olivier, 1999). The effect of nutrition on mohair production has been investigated (McGregor, 1998), but very little work has been done on the effect of different feeding strategies early in life on growth rate and subsequent performance of Angora goats (Huston et al., 1993; Grégoire et al., 1996; Goetsch et al., 2002; Mohrand-Fehr, 2005).

The effect of different pre- and post-weaning management systems, as practiced on-farm in 12 Angora goat studs, on the growth rate of Angora kids from birth to 16 months of age has been investigated. Body weights of young ewes at their first mating at 18 months of age and at the subsequent scanning for pregnancy, and their first kidding performance have also been related to pre-weaning treatment.

\section{Material and Methods}

The data used for this study were collected during a project that involved an investigation into reproductive performance and kid mortality aspects in South African Angora goats. This study was conducted from 2000 to 2004 on 12 South African Angora goat studs, kept under a variety of management systems. Apart from reproductive data, body weights of ewes and kids were recorded at various stages. All management practices and treatments were recorded. The geographical location of and veld types on the different farms and number of kids born during the study period in the different studs are presented in Table 1 . The major management practices followed in the different studs are summarized in Table 2. 
Table 1 Geographical location of and veld type on the different stud farms and number of kids born during the study period on these farm

\begin{tabular}{|c|c|c|c|}
\hline Stud & $\begin{array}{l}\text { Geographical location } \\
\text { of farm }\end{array}$ & $\begin{array}{l}\text { Major veld type } \\
\text { (Acocks, 1988) }\end{array}$ & $\begin{array}{l}\text { Number } \\
\text { of } \\
\text { kids born }\end{array}$ \\
\hline 1 & Murraysburg district & $\begin{array}{l}\text { Karroid broken veld; Great Karoo } \\
\text { (Veld type 26a) }\end{array}$ & 830 \\
\hline 2 & Graaff-Reinet district & $\begin{array}{l}\text { Karroid broken veld; Grassy Mountain } \\
\text { scrub (Veld type 26c) }\end{array}$ & 2055 \\
\hline 3 & Pearston district & $\begin{array}{l}\text { Succulent mountain scrub or } \\
\text { spekboomveld (Veld Type 25) }\end{array}$ & 1522 \\
\hline 4 & Pearston district & $\begin{array}{l}\text { Succulent mountain scrub or } \\
\text { spekboomveld (Veld Type 25) }\end{array}$ & 1166 \\
\hline 5 & Steytlerville district & $\begin{array}{l}\text { Succulent mountain scrub or } \\
\text { spekboomveld (Veld Type 25) }\end{array}$ & 1979 \\
\hline 6 & Beaufort-West district & $\begin{array}{l}\text { Karroid broken veld; Great Karoo } \\
\text { (Veld type 26a) }\end{array}$ & 872 \\
\hline 7 & Jansenville district & $\begin{array}{l}\text { Noorsveld and succulent mountain scrub or } \\
\text { spekboomveld (Veld Types } 24 \text { \& 25) }\end{array}$ & 665 \\
\hline 8 & Jansenville district & $\begin{array}{l}\text { Noorsveld and succulent mountain scrub } \\
\text { or spekboomveld (Veld Types } 24 \text { \& 25) }\end{array}$ & 1014 \\
\hline 9 & Uniondale district & $\begin{array}{l}\text { Karroid broken veld; Little Karoo } \\
\text { (Veld type 26b) }\end{array}$ & 3697 \\
\hline 10 & Jansenville district & $\begin{array}{l}\text { Noorsveld and succulent mountain scrub } \\
\text { or spekboomveld (Veld Types } 24 \text { \& 25) }\end{array}$ & 172 \\
\hline 11 & Jansenville district & $\begin{array}{l}\text { Noorsveld } \\
\text { (Veld Type 24) }\end{array}$ & 1513 \\
\hline 12 & Uniondale district & $\begin{array}{l}\text { Karroid broken veld; Little Karoo } \\
\text { (Veld type 26b) }\end{array}$ & 1159 \\
\hline
\end{tabular}

The final data set analysed for this study contained birth, weaning, 8-, 12- and 16-month body weights of 16644 kids born from 2000 to 2004 in the 12 different studs. Birth, weaning and 8-month body weights were recorded for both ram and ewe kids, while 12- and 16-month body weights were recorded only for the ewe kids. Growth rates for the periods, birth to weaning (ADG : birth to wean), weaning to 8 months (ADG : wean to 8 mo), 8 to 12 months (ADG : 8 mo to $12 \mathrm{mo}$ ) and 12 to 16 months of age (ADG : 12 mo to $16 \mathrm{mo}$ ) were calculated for each kid from its respective body weights.

Body weights of 1914 of the young ewes that were retained in the studs were recorded at their first mating at 18 months of age, as well as when these young ewes were scanned for pregnancy at 21 months of age. The reproductive performance at first kidding in terms of number of kids at scanning, number of kids born, number of kids weaned and weight of kids weaned per ewe, were also recorded.

The General Linear Model (GLM) procedure of the SAS computer package (SAS, 2004) was used to obtain least squares means for the various body weights, growth traits and reproductive parameters. The fixed effects included in the model for birth weight were stud (1-12), year of birth (2000-2004), sex (male and female), birth status of the kid ( 1 or 2 ) and age of dam (2 to 12 years of age). For weaning and 8-month body weights and growth rates from birth to weaning and from weaning to 8 months of age, fixed effects for stud-year-rearing group (SYGR), management group, sex, rearing status of the kid $(11,21,22)$, age of dam and a covariate for age of the kid at weighing (age in days), were included. The reason for including the combined SYGR effect is that different rearing strategies were followed in the different studs from birth to weaning and from weaning to 8 months of age and the rearing groups in the different studs were not the same (Gerstmayr \& Horst, 1995). The management groups included for weaning weight were: Kids maintained on natural veld; kids kept on cultivated pastures for the first few weeks, then moved to veld; kids kept on pastures until weaning. The management groups included for 8-month body weight were kids maintained on veld without supplementation; kids on veld, receiving supplementation and kids kept on pastures. 
Table 2 Management systems followed in the different studs

\begin{tabular}{|c|c|c|c|c|}
\hline \multirow[b]{2}{*}{ Stud } & \multicolumn{4}{|c|}{ Management practices } \\
\hline & During kidding & $\begin{array}{l}\text { From kidding to } \\
\text { weaning }\end{array}$ & $\begin{array}{l}\text { Weaning to } 8 \text { months of } \\
\text { age }\end{array}$ & $\begin{array}{l}\text { Ewe kids after } 8 \\
\text { months of age }\end{array}$ \\
\hline 1 & $\begin{array}{l}\text { Ewes kid in veld, } \\
\text { no supplementation }\end{array}$ & $\begin{array}{l}\text { Twin kids on oat } \\
\text { pastures } \\
\text { Single kids in veld }\end{array}$ & $\begin{array}{l}\text { Kids in veld - no } \\
\text { supplementation }\end{array}$ & $\begin{array}{l}\text { Kids in veld - no } \\
\text { supplementation }\end{array}$ \\
\hline 2 & $\begin{array}{l}\text { Ewes kid on } \\
\text { pastures }\end{array}$ & $\begin{array}{l}\text { Kids on pastures for } \\
\text { first few weeks, then } \\
\text { moved to veld }\end{array}$ & $\begin{array}{l}\text { Ewe kids on veld without } \\
\text { supplementation } \\
\text { Ram kids supplemented }\end{array}$ & $\begin{array}{l}\text { Kids in veld - no } \\
\text { supplementation }\end{array}$ \\
\hline 3 & $\begin{array}{l}\text { Ewes kid on } \\
\text { pastures }\end{array}$ & $\begin{array}{l}\text { Kids on pastures for } \\
\text { first few weeks, then } \\
\text { moved to veld }\end{array}$ & $\begin{array}{l}\text { Kids in veld - no } \\
\text { supplementation }\end{array}$ & $\begin{array}{l}\text { Kids in veld - no } \\
\text { supplementation }\end{array}$ \\
\hline 4 & $\begin{array}{l}\text { Ewes kid on } \\
\text { pastures }\end{array}$ & $\begin{array}{l}\text { Kids on pastures for } \\
\text { first few weeks, then } \\
\text { moved to veld }\end{array}$ & $\begin{array}{l}\text { Ewe kids on veld without } \\
\text { supplementation } \\
\text { Ram kids supplemented }\end{array}$ & $\begin{array}{l}\text { Kids in veld - no } \\
\text { supplementation }\end{array}$ \\
\hline 5 & $\begin{array}{l}\text { Ewes kid on } \\
\text { pastures and in } \\
\text { veld }\end{array}$ & $\begin{array}{l}\text { Kids in different } \\
\text { rearing groups on } \\
\text { veld }\end{array}$ & $\begin{array}{l}\text { Ewe kids on veld without } \\
\text { supplementation } \\
\text { Ram kids supplemented }\end{array}$ & $\begin{array}{l}\text { Kids in veld - no } \\
\text { supplementation }\end{array}$ \\
\hline 6 & $\begin{array}{l}\text { Ewes kid in veld } \\
\text { and on pastures }\end{array}$ & $\begin{array}{l}\text { Kids on pastures for } \\
\text { first few weeks, then } \\
\text { moved to veld }\end{array}$ & $\begin{array}{l}\text { Ewe kids on veld without } \\
\text { supplementation } \\
\text { Ram kids supplemented }\end{array}$ & $\begin{array}{l}\text { Kids in veld - no } \\
\text { supplementation }\end{array}$ \\
\hline 7 & $\begin{array}{l}\text { Ewes kid in veld, } \\
\text { no supplementation }\end{array}$ & $\begin{array}{l}\text { Kids with ewes } \\
\text { in veld }\end{array}$ & $\begin{array}{l}\text { Kids in veld - no } \\
\text { supplementation }\end{array}$ & $\begin{array}{l}\text { Kids in veld - no } \\
\text { supplementation }\end{array}$ \\
\hline 8 & $\begin{array}{l}\text { Ewes kid in veld, } \\
\text { no supplementation }\end{array}$ & $\begin{array}{l}\text { Kids with ewes } \\
\text { in veld }\end{array}$ & $\begin{array}{l}\text { Kids in veld - no } \\
\text { supplementation }\end{array}$ & $\begin{array}{l}\text { Kids in veld - no } \\
\text { supplementation }\end{array}$ \\
\hline 9 & $\begin{array}{l}\text { Ewes kid on } \\
\text { pastures }\end{array}$ & $\begin{array}{l}\text { Kids on pastures for } \\
\text { first few weeks, then } \\
\text { moved to veld }\end{array}$ & $\begin{array}{l}\text { Ewe kids on veld without } \\
\text { supplementation } \\
\text { Ram kids supplemented }\end{array}$ & $\begin{array}{l}\text { Kids in veld - no } \\
\text { supplementation }\end{array}$ \\
\hline 10 & $\begin{array}{l}\text { Ewes kid on } \\
\text { pastures and in } \\
\text { veld }\end{array}$ & $\begin{array}{l}\text { Kids with ewes in } \\
\text { veld }\end{array}$ & $\begin{array}{l}\text { Ewe kids on veld without } \\
\text { supplementation } \\
\text { Ram kids supplemented }\end{array}$ & $\begin{array}{l}\text { Kids in veld - no } \\
\text { supplementation }\end{array}$ \\
\hline 11 & $\begin{array}{l}\text { Ewes kid on } \\
\text { pastures }\end{array}$ & $\begin{array}{l}\text { Kids on pastures for } \\
\text { first few weeks, then } \\
\text { moved to veld }\end{array}$ & $\begin{array}{l}\text { Ewe kids on veld without } \\
\text { supplementation } \\
\text { Ram kids supplemented }\end{array}$ & $\begin{array}{l}\text { Kids in veld - no } \\
\text { supplementation }\end{array}$ \\
\hline 12 & $\begin{array}{l}\text { Ewes kid on } \\
\text { pastures }\end{array}$ & $\begin{array}{l}\text { Kids on pastures till } \\
\text { weaning }\end{array}$ & All kids on pastures & Kids on pastures \\
\hline
\end{tabular}

For the other body weights and growth rates, fixed effects for stud, year of birth, management group (kids ran in veld, received no supplementation; kids ran on pastures), rearing status of the kid, age of dam and a covariate for age of the kid at each body weight, were included. For the reproductive parameters, fixed effects for stud and year were included.

The effect of pre-weaning rearing group on weaning weight and subsequent body weights of 1159 kids in two studs (Stud 1 and Stud 5) where the kids received different treatments before weaning, were obtained from the analysis described above. For this analysis, only body weights for the ewe kids were taken, because weights of ram kids were recorded only up to 8 months of age. Body weights at 18 and 21 months of age and first kidding performance data of 304 young ewes which were part of some of the pre-weaning treatment groups in Studs 1 and 5, were analysed to determine if pre-weaning treatment had any carry-over effect on body weight and kidding performance at 18 months onwards. Fixed effects included for this analysis were stud-year-rearing group. 


\section{Results and Discussion}

The number of records analysed for each trait, as well as the mean and coefficient of variation for each trait is summarized in Table 3. Means as well as minimum and maximum values among studs for birth weight, weaning weight and 8-month body weight of ram kids born from 2000 to 2004 in the different studs are summarized in Table 4. Corresponding data on body weights of the ewe kids from birth to 16 months of age, their body weight at first mating at 18 months of age, their body weight recorded at the subsequent scanning for pregnancy at 21 months of age and their reproductive performance at first kidding, are presented in Table 5.

Table 3 Description of the data set on body weights of kids and first kidding performance of young ewes

\begin{tabular}{lccc}
\hline \multicolumn{1}{c}{ Trait } & $\begin{array}{c}\text { Number of } \\
\text { records }\end{array}$ & Mean & CV (\%) \\
\hline Birth weight (kg) & 16644 & 3.2 & 16.0 \\
Weaning weight (kg) & 11971 & 17.6 & 20.3 \\
ADG : birth to wean (g/day) & 11971 & 113 & 24.4 \\
8 month weight (kg) & 7579 & 22.9 & 16.6 \\
ADG : wean to 8 mo (g/day) & 7579 & 40.0 & 56.7 \\
12 month weight (kg) & 3825 & 20.7 & 16.1 \\
ADG : 8 mo to 12 mo (g/day) & 3825 & 9.0 & 231.0 \\
16 month weight (kg) & 3126 & 24.6 & 16.4 \\
ADG : 12 mo to 16 mo (g/day) & 3126 & 30.0 & 55.0 \\
Body weight before mating (kg) & 1914 & 26.9 & 12.5 \\
Body weight at scan (kg) & 1914 & 30.6 & 12.5 \\
Number of kids scanned & 1914 & 0.78 & 59.5 \\
Number of kids born & 1914 & 0.73 & 69.7 \\
Number of kids weaned & 1914 & 0.58 & 89.1 \\
Weight of kids weaned / ewe & 1914 & 9.4 & 89.5 \\
mated (kg) & & & \\
\hline NG average daily gain; CV & & & \\
\hline
\end{tabular}

$\mathrm{ADG}$ - average daily gain; $\mathrm{CV}$ - coefficient of variation

Table 4 Body weight and growth rate of ram kids from birth to 8 months of age

\begin{tabular}{lrrr}
\hline Trait & $\begin{array}{c}\text { Mean } \pm \text { s.e. } \\
\text { of all studs }\end{array}$ & $\begin{array}{c}\text { Stud with } \\
\text { lowest value }\end{array}$ & $\begin{array}{c}\text { Stud with } \\
\text { highest value }\end{array}$ \\
\hline Birth weight $(\mathrm{kg})$ & $3.28 \pm 0.04$ & $2.60 \pm 0.04$ & $3.39 \pm 0.04$ \\
Weaning weight $(\mathrm{kg})$ & $17.7 \pm 0.3$ & $15.3 \pm 0.3$ & $22.7 \pm 0.3$ \\
ADG : birth to wean (g/day) & $114.4 \pm 2.3$ & $94.6 \pm 2.8$ & $154.4 \pm 2.6$ \\
8 month weight (kg) & $26.8 \pm 0.5$ & $19.4 \pm 0.6$ & $32.3 \pm 0.6$ \\
ADG : wean to 8 mo (g/day) & $61.5 \pm 3.3$ & $21.4 \pm 3.6$ & $100.8 \pm 3.4$ \\
\hline
\end{tabular}


Growth rates of kids in the different studs varied substantially, and this can be ascribed largely to different environments and supplementary feeding practices. The effect of different pre- and post-weaning management systems on body weight and growth rate of the ram and ewe kids from birth to 8 months of age is presented in Table 6. Corresponding data for ewe kids from 12 to 16 months of age are given in Table 7. It is evident that preweaning management system had a significant effect on weaning weight where kids that were kept on pasture until weaning were respectively $5.7 \mathrm{~kg}$ and $4.6 \mathrm{~kg}$ heavier than kids that were kept on the veld and kids that were run on pastures for a few weeks before being moved to the veld. The quantity and quality of feed available to the ewe and the kid therefore contributed significantly to weaning weight. A similar trend was evident in 8-, 12- and 16-month body weights where those kids that ran on pastures or received supplementation on the veld had higher body weights than the kids that were run on the veld without any supplementation.

Table 5 Body weight, growth rate and first kidding performance of ewe kids from birth to 21 months of age

\begin{tabular}{lrrr}
\hline Trait & $\begin{array}{r}\text { Mean } \pm \text { s.e. } \\
\text { of all studs }\end{array}$ & $\begin{array}{c}\text { Stud with } \\
\text { lowest value }\end{array}$ & $\begin{array}{c}\text { Stud with } \\
\text { highest value }\end{array}$ \\
\hline Birth weight (kg) & $2.92 \pm 0.04$ & $2.55 \pm 0.04$ & $3.13 \pm 0.04$ \\
Weaning weight (kg) & $15.3 \pm 0.3$ & $13.3 \pm 0.3$ & $18.8 \pm 0.3$ \\
ADG : birth to wean (g/day) & $97.8 \pm 2.3$ & $80.7 \pm 2.8$ & $125.5 \pm 2.6$ \\
8 month weight (kg) & $18.8 \pm 0.5$ & $17.2 \pm 0.6$ & $23.9 \pm 0.6$ \\
ADG : wean to 8 mo (g/day) & $27.5 \pm 3.2$ & $14.2 \pm 3.3$ & $38.0 \pm 3.4$ \\
12 month weight (kg) & $20.7 \pm 0.3$ & $14.3 \pm 0.4$ & $27.4 \pm 0.3$ \\
ADG : 8 mo to 12 mo (g/day) & $9.0 \pm 2.4$ & $-41.3 \pm 3.5$ & $32.0 \pm 2.2$ \\
16 month weight (kg) & $24.6 \pm 0.7$ & $17.0 \pm 0.8$ & $29.9 \pm 0.7$ \\
ADG : 12 mo to 16 mo (g/day) & $30.0 \pm 2.7$ & $20.5 \pm 2.5$ & $38.8 \pm 2.6$ \\
Body weight before mating (kg) & $26.9 \pm 0.4$ & $20.9 \pm 0.3$ & $35.0 \pm 0.2$ \\
Body weight at scan (kg) & $30.6 \pm 0.4$ & $24.8 \pm 0.3$ & $37.1 \pm 0.2$ \\
Number of kids scanned & $0.79 \pm 0.04$ & $0.41 \pm 0.04$ & $0.99 \pm 0.03$ \\
Number of kids born & $0.73 \pm 0.04$ & $0.20 \pm 0.04$ & $1.00 \pm 0.03$ \\
Number of kids weaned & $0.58 \pm 0.04$ & $0.15 \pm 0.05$ & $0.84 \pm 0.03$ \\
Weight of kids weaned / ewe & $9.4 \pm 0.6$ & $2.0 \pm 0.7$ & $17.7 \pm 0.5$ \\
mated (kg) & & & \\
\hline
\end{tabular}

Growth curves of ram kids from birth to 8 months of age and of ewe kids from birth until 16 months of age are depicted in Figure 1. From these curves it is clear that mean pre-weaning growth performance of both Angora ram and ewe kids under the management systems followed in the participating studs was satisfactory. The same, however, does not apply for post-weaning growth rate. Growth curves in flocks where kids received supplementary feeding after weaning and for studs where kids received no supplementary feeding after weaning are illustrated in Figures 2 and 3 for ram and ewe kids, respectively. In those studs (Studs 2, 4, 5, 11, 12) where all the ram kids received supplementary feeding after weaning, a relatively higher growth rate from weaning until 8 months of age was evident (84 g/day on average), while in those studs (Studs $1,3,7,8$ ) where the ram kids did not receive any supplementary feeding after weaning, a much lower post-weaning growth rate was recorded (39 g/day on average).

Ewe kids, with the exception of Stud 12, usually received no supplementary feeding after weaning. This is evident from Figure 1, where the ewe kids showed little increase in body weight from weaning to 8 months of 
age. The growth rate from weaning to 8 months of age of ewe kids that received supplementation after weaning were $42 \mathrm{~g}$ /day (Stud 12) compared to $28 \mathrm{~g}$ /day on average for studs where ewe kids received no supplementation after weaning.

Table 6 Body weight and growth rate ( \pm s.e.) from birth to 8 months of age of ram and ewe kids ran under different management systems

\begin{tabular}{|c|c|c|c|c|c|}
\hline $\begin{array}{c}\text { Management } \\
\text { system }\end{array}$ & $\begin{array}{c}\text { Number of } \\
\text { kids }\end{array}$ & $\begin{array}{c}\text { Weaning } \\
\text { weight }(\mathrm{kg})\end{array}$ & $\begin{array}{l}\text { ADG:birth to } \\
\text { wean (g/day) }\end{array}$ & $\begin{array}{c}8 \text { month weight } \\
(\mathrm{kg})\end{array}$ & $\begin{array}{c}\text { ADG:wean to } \\
8 \text { mo (g/day) }\end{array}$ \\
\hline Kids ran in veld & 4032 & $14.7 \pm 0.4^{\mathrm{a}}$ & $90.7 \pm 3.4^{\mathrm{a}}$ & & \\
\hline $\begin{array}{l}\text { Kids ran on } \\
\text { pastures for first } \\
\text { few weeks, then } \\
\text { moved to veld }\end{array}$ & 6850 & $15.8 \pm 0.4^{\mathrm{a}}$ & $98.8 \pm 3.3^{a}$ & & \\
\hline $\begin{array}{l}\text { Kids ran on } \\
\text { pastures till } \\
\text { weaning }\end{array}$ & 1030 & $20.4 \pm 0.4^{a}$ & $132.3 \pm 3.4^{\mathrm{a}}$ & & \\
\hline $\begin{array}{l}\text { Kids ran in veld, } \\
\text { received no } \\
\text { supplementation }\end{array}$ & 5042 & & & $20.4 \pm 0.5^{\mathrm{a}}$ & $38.3 \pm 3.3^{a}$ \\
\hline $\begin{array}{l}\text { Kids ran in veld, } \\
\text { received } \\
\text { supplementation }\end{array}$ & 1601 & & & $26.9 \pm 0.5^{\mathrm{a}}$ & $78.9 \pm 3.4^{\mathrm{a}}$ \\
\hline $\begin{array}{l}\text { Kids ran on } \\
\text { pastures }\end{array}$ & 936 & & & $27.7 \pm 0.5^{\mathrm{a}}$ & $55.8 \pm 3.4^{\mathrm{a}}$ \\
\hline
\end{tabular}

${ }^{\mathrm{a}}$ Management groups with the same superscripts differed significantly $(\mathrm{P}<0.01)$ within traits

ADG - average daily gain

Table 7 Body weight and growth rate ( \pm s.e.) from 12 to 16 months of age of ewe kids ran under different management systems

\begin{tabular}{|c|c|c|c|c|c|}
\hline $\begin{array}{l}\text { Management } \\
\text { system }\end{array}$ & $\begin{array}{l}\text { Number of } \\
\text { kids }\end{array}$ & $\begin{array}{c}12 \text { month } \\
\text { weight }(\mathrm{kg})\end{array}$ & $\begin{array}{l}\text { ADG : } 8 \text { mo to } \\
12 \text { mo (g/day) }\end{array}$ & $\begin{array}{c}16 \text { month } \\
\text { weight }(\mathrm{kg})\end{array}$ & $\begin{array}{c}\text { ADG : } 12 \text { mo to } \\
16 \text { mo (g/day) }\end{array}$ \\
\hline $\begin{array}{l}\text { Kids ran in veld, } \\
\text { received no } \\
\text { supplementation }\end{array}$ & 3431 & $22.1 \pm 0.7^{\mathrm{a}}$ & $7.5 \pm 4.7^{\mathrm{a}}$ & & \\
\hline $\begin{array}{l}\text { Kids ran on } \\
\text { pastures }\end{array}$ & 394 & $31.0 \pm 0.8^{a}$ & $29.2 \pm 4.9^{\mathrm{a}}$ & & \\
\hline $\begin{array}{l}\text { Kids ran in veld, } \\
\text { received no } \\
\text { supplementation }\end{array}$ & 2780 & & & $23.4 \pm 0.8^{\mathrm{a}}$ & $30.2 \pm 3.5$ \\
\hline $\begin{array}{l}\text { Kids ran on } \\
\text { pastures }\end{array}$ & 346 & & & $31.9 \pm 0.8^{\mathrm{a}}$ & $32.3 \pm 3.7$ \\
\hline
\end{tabular}

${ }^{\mathrm{a}}$ Management groups with the same superscripts differed significantly $(\mathrm{P}<0.01)$ within traits

ADG - average daily gain

Varying growth rates of ewe kids from 8 to 12 months of age were observed among the different flocks. In some flocks the kids showed an increase in body weight, while in others it remained constant or some even lost weight after 8 months of age. This is also evident from Figure 3 where ewe kids in Stud 12 that were kept on pastures, maintained a steady growth rate of \pm 32 g/day from 8 to 12 and from 12 to 16 months of age. In comparison, the ewe kids kept under veld conditions without any supplementation lost on average $2 \mathrm{~g}$ /day between 8 and 12 months of age. From 12 to 16 months of age the latter ewe kids gained $28 \mathrm{~g} / \mathrm{day}$. This 
phenomenon where especially ewe kids did not grow well after weaning, needs to be investigated further, as it influences the reproductive ability of the young ewes directly.

This is clearly illustrated by the fact that the young ewes in Stud 7, which had the lowest body weight at 18 months of age ( $20.9 \pm 0.3 \mathrm{~kg}$ ), weaned $15 \%$ kids, compared to the ewes in Stud 12, that weaned $84 \%$ kids and had the highest 18 -month body weight $(35.0 \pm 0.2 \mathrm{~kg})$. Furthermore, ewe kids kept under veld conditions without supplementation weaned on average 53\% kids compared to the kids in Stud 12, which weaned 84\% kids. The importance of a sustained level of adequate nutrition of ewe kids after weaning is emphasized in these results.

The effect of pre-weaning rearing group on weaning weight and subsequent body weights of ewe kids born from 2000 to 2004 in Stud 1 and Stud 5 where kids received different treatments before weaning, is presented in Table 8. In Stud 1 pre-weaning treatment did not have any effect on weaning weight or body weight at older ages. In Stud 5 the single kids remained heavier than the other groups up to 18 months of age $(\mathrm{P}<0.01)$. The validity of this should, however, be investigated further, as these data were recorded in a survey study, which means that no scientifically designed experimental procedures were followed. The management and pre-weaning practices as followed by each farmer were used. Since there were no suitable control groups, those groups that did receive supplementation could have performed much worse up to 16 months of age if they did not receive any pre-weaning supplementation.

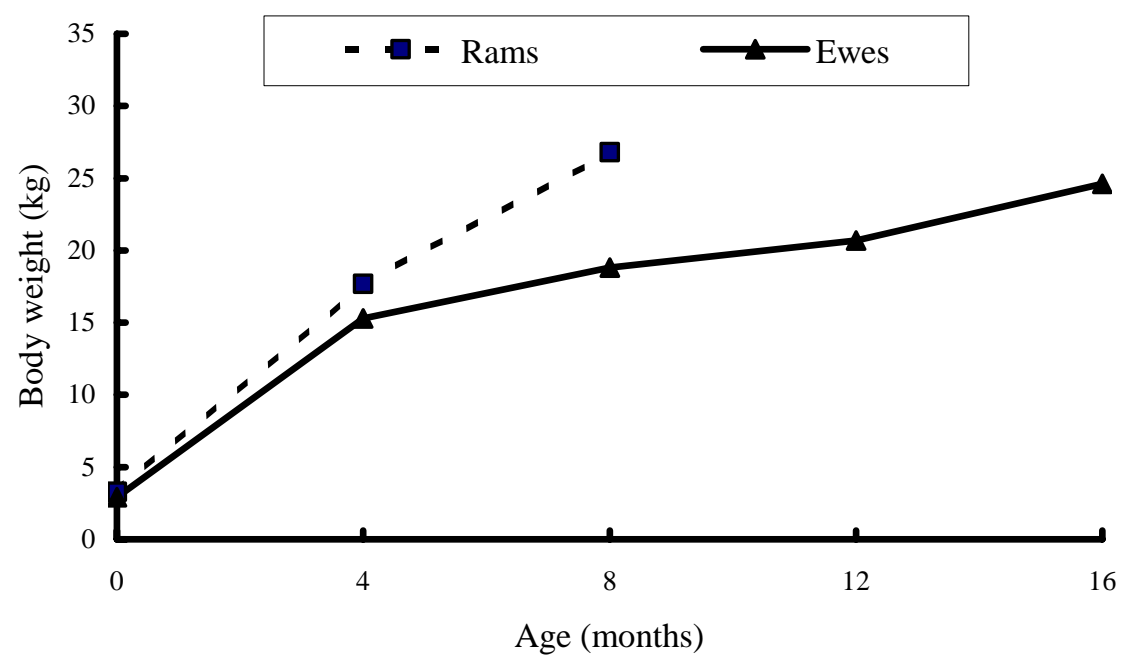

Figure 1 Growth curves of ram kids from birth to 8 months of age and of ewe kids from birth to 16 months of age

Body weights at 18 and 21 months of age and reproductive performance at first kidding of those young ewes that were retained in the stud, are summarized in Table 9. It is evident that the effect of pre-weaning treatment was not carried over to first reproductive performance of the young ewe. These findings are in contrast with studies reported for sheep, where under nutrition during the pre-weaning growth phase had a detrimental effect on first as well as lifetime reproductive performance of ewes (Reardon \& Lambourne, 1966; Alden, 1968; Gunn, 1977; Gunn, 1983; Williams, 1984). However, the findings of this study should be investigated further, because ewe numbers in the treatment groups were low and no comparable control groups were available. 


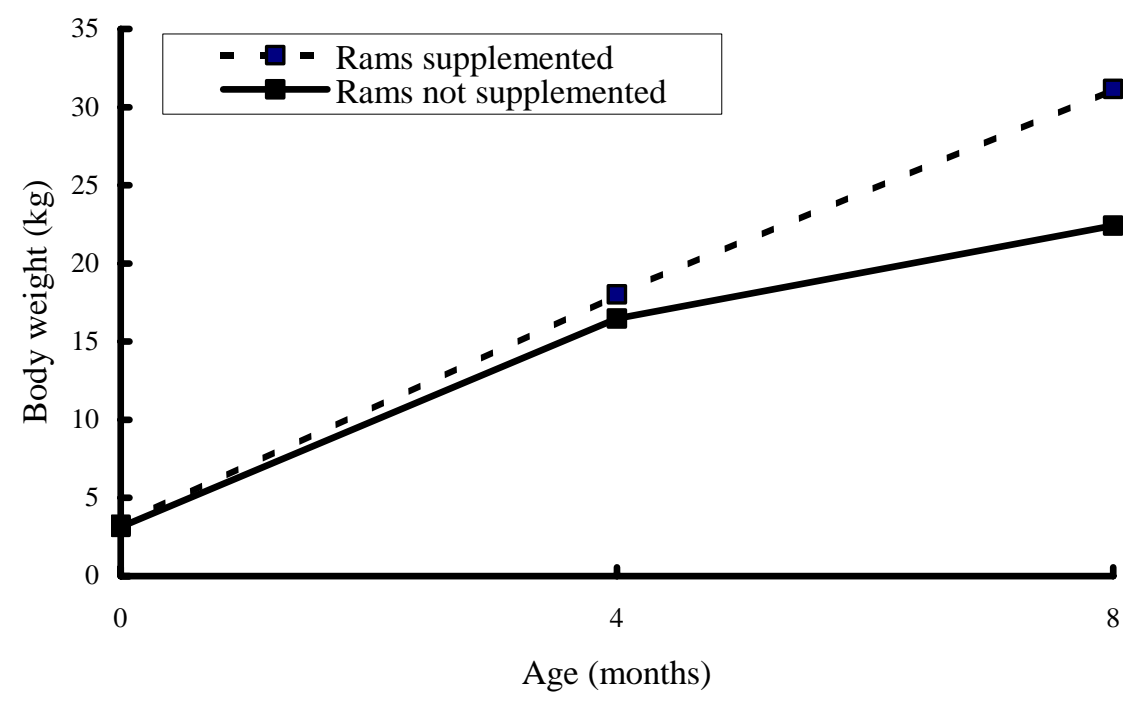

Figure 2 Growth curves of ram kids in studs where ram kids received supplementary feeding after weaning and in studs where ram kids received no supplementation

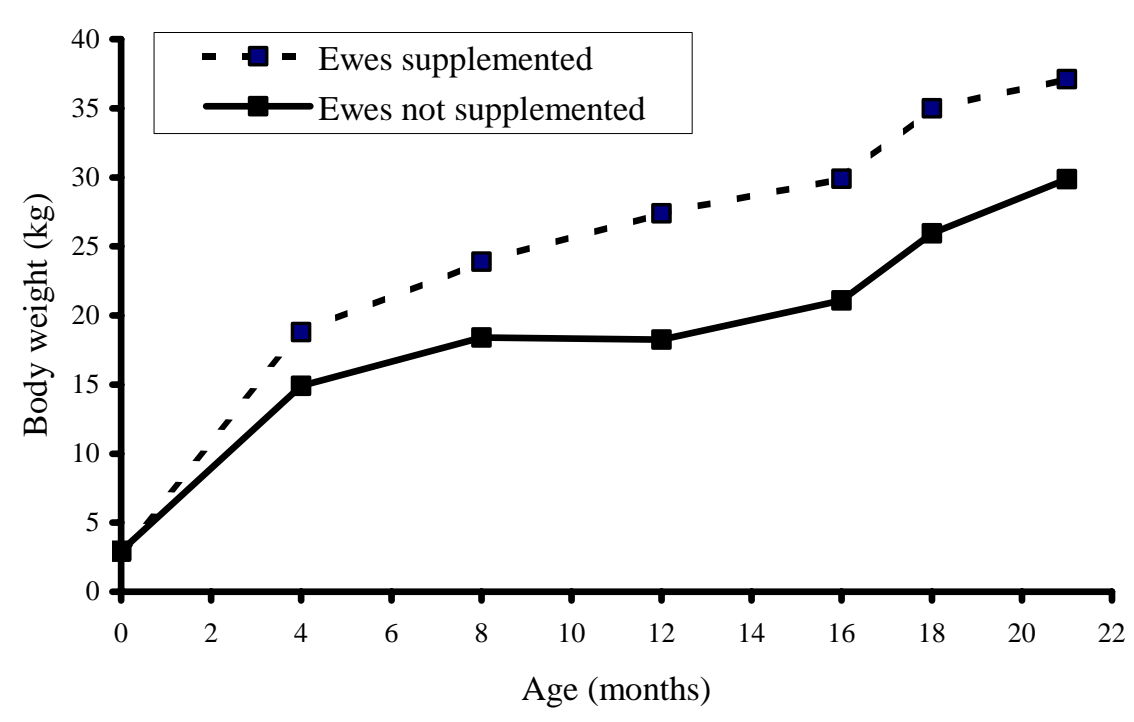

Figure 3 Growth curves of ewe kids in studs where ewe kids received supplementary feeding after weaning and in studs where ewe kids received no supplementation

\section{Conclusions}

It is evident that pre-weaning growth rate of ram and ewe kids under the management systems followed in the participating studs was satisfactory. However, post-weaning growth rate of those kids (ram and ewe) that did not receive supplementary feeding after weaning was unacceptable. The poor growth rate of especially ewe kids after weaning up to 12 months of age is a serious problem that should be addressed, as it directly influences the reproductive ability of the young ewes. This was again evident from the poor reproductive performance of the young ewes in some of the studs. 
Table 8 Effect of pre-weaning rearing group on body weight ( \pm s.e.) of kids born from 2000 to 2004 in two studs (Stud 1 and Stud 5)

\begin{tabular}{lccccc}
\hline $\begin{array}{l}\text { Description of pre-weaning } \\
\text { rearing group }\end{array}$ & $\begin{array}{c}\text { Number of } \\
\text { kids }\end{array}$ & $\begin{array}{c}\text { Weaning weight } \\
(\mathrm{kg})\end{array}$ & $\begin{array}{c}8 \text { month weight } \\
(\mathrm{kg})\end{array}$ & $\begin{array}{c}12 \text { month weight } \\
(\mathrm{kg})\end{array}$ & $\begin{array}{c}16 \text { month weight } \\
(\mathrm{kg})\end{array}$ \\
\hline $\begin{array}{l}\text { Single kids; no } \\
\text { supplementary feeding } \\
\text { (Stud 1) }\end{array}$ & 256 & $15.4 \pm 0.2$ & $19.4 \pm 0.2$ & $22.6 \pm 0.2$ & $25.6 \pm 0.5$ \\
\hline $\begin{array}{l}\text { Twin kids; on oats pastures } \\
\text { (Stud 1) }\end{array}$ & 108 & $15.5 \pm 0.3$ & $19.6 \pm 0.4$ & $22.5 \pm 0.4$ & $26.0 \pm 0.7$ \\
\hline $\begin{array}{l}\text { Single kids; no } \\
\text { supplementary feeding } \\
\text { (Stud 5) }\end{array}$ & 382 & $16.3 \pm 0.1^{\mathrm{ab}}$ & $18.7 \pm 0.1^{\mathrm{ab}}$ & $20.6 \pm 0.2^{\mathrm{a}}$ & $23.4 \pm 0.2$ \\
\hline $\begin{array}{l}\text { Twin kids, supplemented on } \\
\text { veld (Stud 5) }\end{array}$ & 283 & $15.2 \pm 0.2^{\mathrm{a}}$ & $17.5 \pm 0.2^{\mathrm{a}}$ & $19.8 \pm 0.2^{\mathrm{a}}$ & $22.8 \pm 0.2$ \\
\hline $\begin{array}{l}\text { Kids of young ewes, } \\
\text { supplemented on veld } \\
\begin{array}{l}\text { (Stud 5) } \\
\text { a,b,c }\end{array}\end{array}$ & 100 & $14.7 \pm 0.3^{\mathrm{b}}$ & $17.5 \pm 0.3^{\mathrm{b}}$ & $20.0 \pm 0.3$ & $22.9 \pm 0.4$ \\
\hline
\end{tabular}

Table 9 Effect of pre-weaning rearing group on body weight and reproductive performance ( \pm s.e.) of young ewes in two studs (Stud 1 and Stud 5)

\begin{tabular}{|c|c|c|c|c|c|c|}
\hline $\begin{array}{l}\text { Description of pre-weaning } \\
\text { rearing group }\end{array}$ & $\begin{array}{l}\text { Number of } \\
\text { ewes }\end{array}$ & $\begin{array}{l}18 \text { month } \\
\text { weight }(\mathrm{kg})\end{array}$ & $\begin{array}{l}21 \text { month } \\
\text { weight }(\mathrm{kg})\end{array}$ & $\begin{array}{c}\text { Number of } \\
\text { kids scanned }\end{array}$ & $\begin{array}{l}\text { Number of } \\
\text { kids born }\end{array}$ & $\begin{array}{c}\text { Number of } \\
\text { kids weaned }\end{array}$ \\
\hline $\begin{array}{l}\text { Single kids; no } \\
\text { supplementary feeding } \\
\text { (Stud 1) }\end{array}$ & 59 & $31.1 \pm 0.7$ & $33.6 \pm 0.9$ & $0.85 \pm 0.06$ & $0.77 \pm 0.07$ & $0.65 \pm 0.07$ \\
\hline $\begin{array}{l}\text { Twin kids; on oats pastures } \\
\text { (Stud 1) }\end{array}$ & 30 & $30.8 \pm 0.7$ & $33.1 \pm 0.9$ & $0.67 \pm 0.08$ & $0.61 \pm 0.10$ & $0.51 \pm 0.11$ \\
\hline $\begin{array}{l}\text { Single kids; no } \\
\text { supplementary feeding } \\
\text { (Stud 5) }\end{array}$ & 140 & $28.2 \pm 0.3^{\mathrm{a}}$ & $31.9 \pm 0.3$ & $0.80 \pm 0.05$ & $0.77 \pm 0.05$ & $0.57 \pm 0.05$ \\
\hline $\begin{array}{l}\text { Twin kids, supplemented } \\
\text { on veld (Stud 5) }\end{array}$ & 57 & $27.2 \pm 0.4^{\mathrm{a}}$ & $31.1 \pm 0.5$ & $0.71 \pm 0.06$ & $0.71 \pm 0.07$ & $0.59 \pm 0.07$ \\
\hline $\begin{array}{l}\text { Kids of young ewes, } \\
\text { supplemented on veld } \\
\text { (Stud 5) }\end{array}$ & 18 & $27.7 \pm 0.7$ & $31.1 \pm 0.9$ & $0.86 \pm 0.11$ & $0.86 \pm 0.12$ & $0.55 \pm 0.13$ \\
\hline
\end{tabular}

From the results of this survey it seems as if viable mohair production under natural veld conditions is not possible without supplementation of kids during pre- and post-weaning. The results obtained with this survey further supplied a good basis for scientific research into specific aspects since it is evident that post-weaning growth and nutrition is a critical period in the productive cycle of the Angora goat.

\section{Acknowledgements}

The author wishes to convey her sincere appreciation to all people who participated in the project and to Mohair South Africa for funding the project.

\section{References}

Acocks, J.P.H., 1988. Veld types of South Africa. Memoirs of the botanical survey of South Africa No 57. $3^{\text {rd }}$ edition. Botanical Research Institute, Dept. Agric. and Water Supply, Pretoria, South Africa. pp. 65-71.

Allden, W.G., 1968. Undernutrition of Merino sheep and its sequelae. III. The effect of lifetime productivity of 
growth restrictions imposed at two stages of early postnatal life in a Mediterranean climate. Aust. J. Agric. Res. 19, 621-639.

Gerstmayr, S. \& Horst, P., 1995. Estimates of performance traits in Turkish Angora goats. Small Rumin. Res. 16, 141-157.

Gifford, D.R., Ponzoni, R.W., Lampe, R.J. \& Burr, J., 1991. Phenotypic and genetic parameters of fleece traits and live weight in South Australian Angora goats. Small Rumin. Res. 4, 293-302.

Goetsch, A.L., Detweiler, G. \& Sahlu, T., 2002. A note on the effects of preweaning concentrate supplementation on performance of meat goats. J. Appl. Anim. Res. 21, 25-34.

Grégoire, R.J., Fahmy, M.H., Boucher, J.M., Tremblay, A. \& Mercier, J., 1996. Effect of four protein supplements on growth, feed conversion, mohair production, fibre characteristics and blood parameters of Angora goats. Small Rumin. Res. 19, 121-130.

Gunn, R.G., 1977. The effects of two nutritional environments from 6 weeks pre-partum to 12 months of age on lifetime performance and reproductive potential of Scottish Blackface ewes in two adult environments. Anim.. Prod. 25, 155-164.

Gunn, R.G., 1983. The influence of nutrition on the reproductive performance of ewes. In: Sheep Production. Ed. W. Haresign, Butterworths, London. pp. 99-110.

Huston, J.E., Taylor, C.A., Lupton, C.J. \& Brooks, T.D., 1993. Effects of supplementation on intake, growth rate and fleece production by female Angora kids grazing rangeland. J. Anim. Sci. 71, 3124-3130.

McGregor, B.A., 1998. Nutrition, management and other environmental influences on the quality and production of mohair and cashmere with particular reference to Mediterranean and annual temperate climate zones: A review. Small Rumin. Res. 28, 199-215.

Mohrand-Fehr, P., 2005. Recent developments in goat nutrition and application: A review. Small Rumin. Res. 60, 25-43.

Nicoll, G.B., 1985. Estimates of environmental effects and some genetic parameters for weaning weight and fleece weights of young Angora goats. Proc. New Zealand Soc. Anim. Prod. 45, 217-219.

Nicoll, G.B., Bigham, M.L. \& Alderton, M.J., 1989. Estimates of environmental effects and genetic parameters for live weights and fleece traits of Angora goats. Proc. New Zealand Soc. Anim. Prod. 49, 183-189.

Reardon, T.F. \& Lambourne, L.J., 1966. Early nutrition and lifetime reproductive performance of ewes. Proc. Aust. Soc. Anim. Prod. 6, 106-108.

SAS, 2004. SAS Procedures Guide, Version 9.1. Cary, NC, SAS Institute Inc.

Snyman, M.A. \& Olivier, J.J., 1996. Genetic parameters for body weight, fleece weight and fibre diameter in South African Angora goats. Livest. Prod. Sci. 47, 1-6.

Snyman, M.A. \& Olivier, J.J., 1999. Repeatability and heritability of objective and subjective fleece traits and body weight in South African Angora goats. Small Rumin. Res. 34, 103-109.

Van der Westhuizen, J.M., Wentzel, D. \& Grobler, M.C., 2004. Reproduction. In: Angora goats and mohair in South Africa - 2004 Revised ed. Mohair South Africa, P.O. Box 2243, Port Elizabeth 6056, South Africa.

Williams, A.H., 1984. In: Reproduction of sheep. Eds. Lindsay, D.R., Pearce, D.T. Australian Academy of Science in conjunction with the Australian Wool Corporation, Canberra. pp. 272-273.

Yalcin, B.C., 1982. Angora goat breeding. Proc. 3rd Int. Conf. Goat Prod. Disease, Tucson, Arizona. pp. 269278. 